\title{
Research on the National Style of Granados's Six Pieces of Spanish Folk Sketches
}

\author{
Hong Cheng, Shangfeng He \\ School of Music, Zhejiang Normal University, Jinhua, China \\ Email: 1604495791@qq.com
}

How to cite this paper: Cheng, $\mathrm{H}$. and $\mathrm{He}$, S.F. (2021) Research on the National Style of Granados's Six Pieces of Spanish Folk Sketches. Open Access Library Journal, 8: e8210.

https://doi.org/10.4236/oalib.1108210

Received: November 21, 2021

Accepted: December 14, 2021

Published: December 17, 2021

Copyright $\odot 2021$ by author(s) and Open Access Library Inc.

This work is licensed under the Creative

Commons Attribution International

License (CC BY 4.0).

http://creativecommons.org/licenses/by/4.0/

\begin{abstract}
This article takes Granados as the research horizon, with its Six Pieces of Spanish Folk Sketches national style as the research, on the basis of collection, sorting, reading literature, map to the national style of Granados's Six Pieces of Spanish Folk Sketches and dynamic theory, aims to promote their own understanding of the national style, to lay a theoretical foundation for the future play his works.
\end{abstract}

\section{Subject Areas \\ Sketch National Style}

Keywords

Granados, Spanish, Folk Songs, National Style, Six Pieces of Spanish Folk Sketches

\section{Introduction}

Spanish music experienced a long absorption and evolution, at the end of the 19th century, the "Spanish ethnic music". The 19th century was a development period of the national liberation movement. A large number of musicians began to pay attention to their own national style and cultural connotation, which is also an inevitable reflection of the national movement in the field of culture and art. The composers of the national music school borrowed from some foreign creation techniques, and integrated into the traditional Spanish national dance rhythm, guitar, folk tune and other music elements, so that the Spanish music creation also entered its peak. Granados was an important representative of the Spanish music group in the second half of the 19th century, known as "Chopin of Spain" and a great piano composer, performer and music educator. It inhe- 
rited the classical and romantic composition techniques and style at the same time, also cleverly combines the style of the Spanish nation, makes the classical rules and Spanish folk style fusion, lets the romantic personal thoughts and Spanish enthusiasm like fire collision, to create the unique characteristics of national style.

This paper mainly focuses on the national style of the "Six Pieces of Spanish Folk Sketches", which aims to analyze the creative characteristics of the "Six Pieces of Spanish Folk Sketches", and to further understand the embodiment of the Spanish national style.

For me, I searched 100 related literatures on the piano study of Granados works, including 46 academic journals and 54 degree papers. It can be seen that there are many studies on Granados' piano works, however, there is only one literature about the national style of the "Six Pieces of Spanish Folk Sketches". Therefore, the research of this topic still has certain research value. This paper mainly studies the national style of the "Six Pieces of Spanish Folk Sketches", which is mainly divided into the formation and development of the Spanish folk music groups, the piano music creation of Granados, and the national style embodiment of the "Six Pieces of Spanish Folk Sketches".

\section{The Formation and Development of Spanish Ethnic Music}

Spain was the ancient capital of civilization, located in the Iberian Peninsula to the southwest of Europe. Near the Mediterranean to the east, Portugal to the west and the Atlantic to the north, it is one of the alpine countries in Europe. Spain's unique and charming national music, such as dance flamenco, bullfighting, guitar and rattles, are well known. Representatives of the Spanish ethnic music were Pedrell, Albenes, de Fah and Dulina.

The formation and development of Spanish music is also closely related to the historical background of Spain. In 2012, Gu Xin published her article "Granados's Song of Life '12 Spanish Dance Songs"' in 2012 [1], which mentioned that in $218 \mathrm{BC}$, the Romans invaded Spain, so the chant of the Christian Church was called the main body of Spanish music at that time. From the beginning of the 8th century BC to the end of the 15th century, Spain was ruled by the Arab Moors, and the Arabs brought new instruments such as horizontal flute, ring board, tambourine, which influenced the Spanish style of the music. During this period, Spanish music was diversified due to the invasion of various countries. Spain was unified from the 15th to 17th centuries, and this period was also the Renaissance of Spanish music. Then, with the outbreak and development of the national revolution, and the establishment of the Spanish National Opera House, the Madrid Conservatory of Music and the Barcelo Conservatory, Spain also ushered in a more brilliant golden period. This produced the Spanish ethnic music.

The formation and development of the Spanish ethnic music roughly includes eight historical periods, before the medieval, medieval, Renaissance, Baroque, 
classical, Golden, the early 20th century, and after the 20th century. In 2015, Bao Shuang published the formation and development of piano folk music in Spain [2] and summarized briefly to the development of Spanish piano folk music: Firstly, previous medieval Spanish music retained the characteristics of ancient Greek music on the basis of combining ancient Roman and Arab music, which is as practical and hedonic as Spanish architectural art; Secondly, medieval Spanish music is in sharp contrast to its history. Spain was in the dark period, but its music was bound by medieval Christian culture, people yearn for freedom, thus the birth of secular music, and became popular with the ordinary people, along with the emergence of many kinds of secular music, with religious music and secular music developed side by side. Two secular songs of Kantijia and the ballad are popular in Spain; Thirdly, Renaissance Spanish music produced a large number of personalized music works and a large number of piano works with national style. With the prevalence of literature and art, Spanish religion was reformed and further influenced the art of music, mainly reflected in the harmony is no longer limited by tone, greatly expanded the expansion of melody, selective application of fugue techniques, etc. Secular music is not under the control of church music, Villancico and Romantic Music began to prevail; Fourthly, The birth of opera not only set off a climax to the Baroque music, but Spain also created the opera of its own nation, mainly with happy opera and court entertainment opera. National opera of Zarzuela also appeared in some areas of Spain. By the late Baroque, the keyboard theory book "Sonata for organ and keyboard music" to the development of Spanish keyboard music; Fifthly, classical Spanish music has a great development in opera, some composers put Zarzuela to the stage, this music with small corresponding parts began to prevail in the country; Sixthly, the late 19th century and early 20th century were the golden period of Spanish piano music, and composers more advocated the release of individuality, self-affirmation, self-imagination and self-catharsis, and more personalized and emotional in expression skills. The musical mainstream of this period was the romantic music faction, which coexisted with it. Ethnic music schools mainly develop and promote the music art of the Spanish nation. The composers also add music genres and art forms with the Spanish national style in the process of creation, thus giving vitality to the work. During this period, Spanish piano national music has gained a world reputation, established in Madrid and Barcelona, trained a large number of music talents, and made Spanish music education diversified in the 20th century. At this time, by national civil war and social changes, many music genres, music styles are also prominent, representative expressionist music, nationalist music, sequence music, neoclassical music, new romantic music, incidental music and so on. The creative styles of the musicians in this period are varied, not limited to the same music style, but few ethnic elements appeared in the piano music works of this period, but instead introduced many mainstream European music elements. It was not until the end of the Spanish Civil War that nationalist music began to become active, and nationalist musicians mainly took folk stories, used folk materials to create, 
and carry forward the national spirit.

Representatives of the Spanish ethnic music were Felipe Pedrell, Isaac Albeniz, Manuel De Falla and Joaquin Turina. Felipe Pedrell (1841-1922) was a pioneer of the Spanish ethnic music. He highly advocates folk music and believes that "folk songs are our music". His creative style was not influenced by the historical background of the time, and the work was full of the spirit of Spanish national music. As a music teacher, he deeply influenced a large number of Spanish national composers. Isaac Albeniz (1860-1909) was the famous Spanish pianist, composer, studied under Friedrich List. He was closely related to Xiao Song and Dandi, which is deeply influenced by the French music atmosphere, but he has still created a large number of works closely related to the Spanish music culture. Representative works are Iberia and so on. Manuel De Falla (1876-1946) was the leader of modern Spanish piano music, his piano first teacher was his mother. It was very interested in Spanish national music, and is more about it to study the charm and essence of country music. Its later musical style has the characteristic of Impressionist music. Its works were also typical of Spanish national music, and the representative works include Bettica Fantasia and so on. Joaquin Turin (1882-1949) was the outstanding Spanish pianist, composer. Its early creation had the characteristics of French music style, while in the later stage, the traditional works of the Spanish nationality were created, and it formed a unique style with French creative technical techniques and Spanish style of national music. Representative works are Serbia, etc.

Spanish national music can get rapid development, cannot leave Russia's "powerful group", Smetana, Sibelius, Grieg and other parts of Europe ethnic music group constantly lead, the composer weakened the people's life, more is based on absorbing folk various materials for the script on the basis of sublimation and innovation.

\section{Piano Music Creation by Granados}

Enrique Granados (1867-1916), he is one of Spain's greatest romantic composers. He studied composition with the famous composer and educator Pedrel in 1883, and the piano under the direction of the pianist Charles Berio in 1887. In 1885, Granados gave his first solo concert in Barcelona, before also working with multiple musicians. It is also an eminent music educator, founding the Barcelona Classical Music Society and the Granados Conservatory of Music, producing many notable musicians.

The important embodiment of the national style of Granados' piano works also lies in its absorption and application of the melody of Spanish folk music. Lin Chen published in 2020 the national characteristics of Granados piano works and performance interpretation [3], which talked about Granados in its piano works in various adopted Spain different folk music melody winter, and creatively into its piano music creation, reflects the strong unique charm of Spanish folk music. The national style of his works is mainly reflected in the reference of 
the "deep song" type melody. "Deep Song" is a very popular folk song in southern Spain. It is smooth and ethereal, serious, deep and full of change, and full of inner tension. Granados does not directly cite a specific "deep song” melody, but based on the characteristics of the starting vocal range, timbre and other aspects, is this melodic feature is more rich on the piano. Another is the use of the rich rhythmic characteristics in the Spanish flamenco dance, Khoda dance, Fontano dance, tango dance and Cecilia dance. Shi Chenchen published "The Chopin of Spain" in 2019 [4], which also analyzed the ethnic characteristics of Granados piano music in the work. Among them, Granados mainly analyzed the melody adoption of Spanish Folk sketches, the performance grasp of the Spanish dance rhythm weaving, and the piano skills imitating the guitar stereo.

In conclusion, Granados' piano music creation can be divided into the early, middle, and late stages. His early works were mainly composed of piano sketches with strong Spanish nationalism. The middle works have romantic style color; The late works are the most mature period of his creation, with profound content, rich creation techniques and difficult performance skills. The style of the piano works can be summarized as follows: with a strong Spanish folk song style and with a romantic color. It is mainly taking the Spanish national style color as the tone of its work, in the application of classical doctrine, romanticism and impressionism. Its piano works in the creation, the skills are not very complex, pay more attention to the more delicate emotion and more rich sound color.

\section{The National Style of Granados's Six Pieces of Spanish Folk Sketches}

Six Pieces of Spanish Folk Sketches are another set of songs featuring Spanish folk music elements after writing the Twelve Spanish Dance Songs. The whole song is full of enthusiasm and vitality. Mainly included Prelto, Memory, Holiday Memories, Basque Dance, Eastern March, Zaba, and Foot Dance.

Six Pieces of Spanish Folk Sketches are full of Granados' use of Spanish Folk sketches, which uses a rich dance rhythm and uses gorgeous and sophisticated piano playing skills. Liu Shushu in his Granados and his on six Spanish folk sketch: Prelude is six Spanish folk song [5], pipa tone to imitate the guitar, the prelude gives a feeling of being in the Iberian peninsula; Miss is the first sketch, the music begins with intensive six double chords, give a person a lively and happy feeling, followed by the lyrical main melody, with a trace of sadness, let a person think of the history of the Iberian peninsula. The loud lyrical melody of the second theme is combined with the bass jumping triple sound to reflect the rhythm of the rhythmic Hordance; the second theme of the second Memories of the Festival appeared, with Bolero dance rhythm and full of festive atmosphere; The Basque Dance is the third sketch. Basque is a type of Spanish folk dance music. The prelude uses a roaring, magnificent effect, Granados uses continuous alternating octaves, the vocal range across three octaves, with 32 notes left and right alternately, giving a lively atmosphere, which seems to be the Basques dur- 
ing their grand festival; The Eastern March is the fourth work. The music begins with high and low octaves, followed by the continuous bass use of tap beats, where the latter sixteenth alternating with the fast sixteenth, giving a strong Spanish ethnic style. The middle part has a small part of the transfer tone, and then into a slightly slow walking board, giving people a strong Oriental color; the fifth Zanba dance song is a very strong Spanish national style sketch. The prelude is played by a bold and fast descending semis phonic tone, showing the rough madness and enthusiasm of Spain. The song also uses the typical folk dance song "Serbia" rhythm, while also imitating the effect of the guitar dial; the last song is the climax of the whole set, the whole song is full of enthusiasm. Music using $6 / 8$ beat rhythm, bass using three beats of continuous sound, loud part continuous upward double mode, the opening gives a person with a strong dance dynamic effect, then Granados through the rhythm accent change to show clog dance sound effect, make the music is full of high and bold and unrestrained gas.

Granados's Six Spanish Folk Sketches is its more successful suite, smooth melody, both the use of Basque folk dance rhythm, and guitar string instruments, full of strong Spanish style. The song is full of Granados' use of Spanish folk, with a rich dance rhythm and gorgeous and sophisticated piano playing techniques. It can be seen that the national style of Granados' six "Spanish folk sketch" reflects incisively and vividly.

\section{Conclusion}

The national style in Granados's Six Spanish Folk Sketches is reflected in the author's full use of Spanish national folk songs, and the introduction of the typical Spanish dance rhythm. This shows Granados's deep piano creation skills and his love for the Spanish nation. As an important founder of the development of the Spanish national music group, the works created by Granados have also provided a strong support for the Spanish national music. In his ordinary practice and performance, the author can more and more feel the talent of Granados, and the most important thing is his deep love for his motherland in his piano music. As the new youth of the twenty-1st century, we should learn from Granados about his patriotism. When I had a deeper understanding of his works, I also felt his love for Spanish national music when writing. As Chinese people in the new era, we should pass on the pursuit of excellent traditional Chinese culture and the pious attitude of national belief. Under the background of The Times, we should continue to continue the national creation journey, keep pace with The Times, constantly seek and explore the national music factors with Chinese characteristics, and integrate and apply them into the creation process of piano music. The author just made a relatively simple review here, because the relatively shallow experience for the collation and analysis of the literature is not particularly in-depth, but will continue to have an in-depth understanding, to lay a good foundation for the later learning. 


\section{Conflicts of Interest}

The authors declare no conflicts of interest.

\section{References}

[1] Gu, X. (2012) Granados Life Song-12 Spanish Dance Songs. Master's Thesis, Tianjin Conservatory of Music, Tianjin.

[2] Bao, S. (2015) Formation and Development of Spanish Piano Folk Music. Master's Thesis, Jilin University, Jilin.

[3] Lin, C. (2012) Ethnic Characteristics and Performance Interpretation of Granados Piano Works. Master's Thesis, Fujian Normal University, Fuzhou.

[4] Shi, C.C. (2019) The Chopin of Spain. Master's Thesis, North Central University, Taiyuan.

[5] Liu, S.S. (2020) Granados with His "Six Spanish Folk Sketches”. Art Review, No. 5, 27-28. 